\title{
Response of Zaghloul Date Palms Grown in New Reclaimed Lands to Application of Organic and Bio Nitrogen Fertilizers
}

\author{
Saad, R. I.; Kh. A. Roshdy, and Nagwa, A. Abd El-Mgeed ${ }^{1}$
}

\begin{abstract}
The present study was carried out during three seasons i.e. 2008, 2009 and 2010 on Zaghloul date palms grown in sand silty soil under surface irrigation in new reclaimed land in Mariot sector. The aim of this study was to investigate response of Zaghloul date palms to application of organic and bio nitrogen fertilizers along with mineral $\mathrm{N}$ and their combinations (11 treatments). The obtained results indicated that, all studied treatments of mineral, organic and bio nitrogen combinations were effective in improving yield, fruit quality and leaf mineral content compared with those of the control treatment (unfertilized) and $100 \%$ mineral nitrogen treatment. It was abvious that, the superior treatment which exerts positive effects on yield/palm, fruit and pulp weight, flesh thickness, TSS\%, total and reducing sugars and leaf NPK content was treatment no.10 $(25 \%$ Min. $N+50 \%$ Org. $N+$ Bio. N) followed descendingly with treatment no.3 (50\% Min. N $+\mathbf{5 0 \%}$ Org. N). In the meantime, both of treatment no.6 $(100 \%$ Org. $N+$ Bio. $N)$ followed descendingly by treatment no. 10 (above mentioned) were the most effective in inhancing fruit dimensions and leaf $\mathrm{Fe}, \mathrm{Mn}, \mathrm{Zn}$ content.

It could be concluded that, under the conditions of this study, $25 \%$ mineral nitrogen $+50 \%$ organic nitrogen + Bio nitrogen treatment was very superior one for minimizing the use of mineral nitrogen fertilization to the quarter, reducing environmental pollution and producing an economical yield with best fruit quality of Zaghloul date palms in new reclaimed lands.
\end{abstract}

Key words: Zaghloul date palms, mineral nitrogen, organic nitrogen -Nitrobin.

\section{INTRODUCTION}

Date palm (Phoenix dactylifera $\mathrm{L}$.) is considered as one of the most commerical and popular crop, so in some religious occasions, this crop occupies a special status in many countries of the world, especially in Egypt as a result of the nutritional value of fruits and due to its uses. In addition, date palms thrive well under drastic environmental conditions of many desert areas. Therefore, growers apply large amounts of chemical fertilizers to improve fertility of these new reclaimed soils and to increase palm yield. However, excessive amount of chemical fertilizers applied during the agricultural practices nowdays lead to many environmental problems such as nitrate pollution of soil and ground water. In addition, such fertilizers can alter the composition of fruits, vegetables and root crops, and decrease their contents of vitamins, minerals and other compounds. Apparently, harmful residues that remain in food pose threats to health (Bogatyre, 2000; Al-Wasfy and El-Khawaga, 2008).

Additionally, in Egypt the annual production of mineral $\mathrm{N}$ fertilizers is not enough to meet the local requirements especially with increasing the area of ready reclaimed land which in turn leads to raise the prices of such fertilizers.

Nowadays, great attention is paid to attract the growers to use organic and biofertilizers as partial substitute for mineral nitrogen fertilizers to avoid these environmental and economical problems.

Organic fertilization for fruit crops became a good alternative to chemical fertilization to avoid pollution of environment (Blake, 1990). Organic manure not only increase of the organic matter in soil but also increased the available phosphorus, exchangeable potassium, calcium and magnesium content (Bhangoo et al., 1988), also organic fertilization improved soil porosity, infilitration rate and soil water retention (Asker et al., 1994 and Nassar, 1998).

Biofertilizers as (Nitrobin) containing nitrogen fixing bacteria could be used as source for fixing nitrogen in the soil. Several processes other than nitrogen fixation could be acount for the positive effect of biofertilizer, including production of growth regulators, protection from root pathogens and modification of nutrient uptake by plant (Techan, 1988 and Gogoi et al., 2004). Studies in this respect revealed that inoculation with $\mathrm{N}$ biofertilizer could save half the normal field rate of $\mathrm{N}$ chemical fertilizers and at the sametime, promote plant production (Ishac, 1989).

Previous studies emphasized the great benefits of using organic and bio nitrogen fertilizers in combination with mineral nitrogen fertilizer in terms of total yield of trees (Umesh et al., 1988; Hussein et al., 1992; Abd ElNaby \& Gomma, 2000; Geetha \& Nair, 2000; Shaheen et al., 2003; Diab, 2006; Rabie \& Saad, 2007 and Abd El-Salam et al., 2009). Also, other related studies were recorded by Tiwary et al., 1988; Mansour, 1998; Tachibana \& Yahata, 1998; Joo et al., 1999; Osman, 2003; Abd El-Hameed \& Ragab, 2004; Mohamed \& Gobara, 2004 and El-Assar, 2005. They pointed to the positive effect of organic and bio nitrogen fertilizers on 
physical and chemical properties of fruits in different fruit crops. As well as, Smith et al., 1994; Soliman, 2001; Magda, 2002; Mansour et al., 2004; El-Shenawi \& El-Sayed, 2005; Mai et al., 2005; Basma \& Telep, 2008 and Hossam El-Deen \& Boshra, 2008 revealed that organic and bio nitrogen applications had considerable effect on leaf mineral contents of some fruit cultivars.

Therefore, the aim of the present study was to investigate the effect of chemical, organic and bio nitrogen fertilizers and their combinations on yield, fruit quality and leaf mineral content of Zaghloul date palms grown in new reclaimed lands. The final target is to produce a safe and healthy food free from chemical pollutants.

\section{MATERIALS AND METHODS}

The present study was conducted during 2008, 2009 and 2010 seasons on 10 years old Zaghloul date palms grown in Khoraish orchard at Mariout sector, Alexandria Governorate. Physical and chemical properties of experimental site were determined at the beginning of the treatments according to Wilde et al. (1985) and the obtained data are shown in Table (1).

Forty-four uniform palms planted at $8 \times 8$ meters apart were selected for the applications of treatments. Normal cultural practices were followed as usual for date palms and all selected palms were artificially hand pollinated using pollen grains from a certain source during the three experimental seasons. This study included the following eleven treatments for single and combined applications of mineral, organic and bio nitrogen fertilizers as follows:

\begin{tabular}{clccc}
\hline \multirow{2}{*}{ No. } & \multicolumn{2}{c}{ Treatments } & \multicolumn{2}{c}{ Amounts of fertilizer (Kg/palm/year)* } \\
\cline { 3 - 5 } & & $\mathbf{2 0 0 8}$ & $\mathbf{2 0 0 9}$ & $\mathbf{2 0 1 0}$ \\
\hline 1 & $100 \% * *$ Mineral nitrogen (Min.N) & 4.9 & 4.9 & 4.9 \\
2 & $100 \%$ Organic nitrogen (Org.N) & 96.0 & 93.0 & 89.0 \\
3 & Bio-nitrogen fertilizer (Bio.N) & Bio-N & Bio-N & Bio-N \\
4 & $100 \%$ Min.N + Bio.N & $4.9+$ Bio.N & $4.9+B i o . N$ & $4.9+B i o . N$ \\
5 & $100 \%$ Org.N + Bio.N & $96.0+B i o . N$ & $93.0+B i o . N$ & $89.0+B i o . N$ \\
6 & $50 \%$ Min.N + 50\% Org.N & $2.5+48.0$ & $2.5+46.5$ & $2.5+44.5$ \\
7 & $50 \%$ Min.N + Bio.N & $2.5+B i o . N$ & $2.5+B i o . N$ & $2.5+B i o . N$ \\
8 & $50 \%$ Org.N + Bio.N & $48.0+B i o . N$ & $46.5+B i o . N$ & $44.5+B i o . N$ \\
9 & $25 \%$ Min.N + 50\% Org.N & $1.3+48.0$ & $1.3+46.5$ & $1.3+44.5$ \\
10 & $25 \%$ Min.N+50\%Org.N+Bio.N & $1.3+48.0+B i o . N$ & $1.3+46.5+B i o . N$ & $1.3+44.5+B i o . N$ \\
11 & Control (Unfertilized palms)*** & - & - & - \\
\hline
\end{tabular}

*According to the chemical analysis of experimental organic fertilizer (FYM) in Table (2).

$* * 100 \%=$ Recommended rate of actual nitrogen $=1000 \mathrm{gms} / \mathrm{palm} / \mathrm{year}$.

*** Unfertilized with any nitrogen fertilizers.

Table1. Physical and chemical analysis of experimental soil orchard

\begin{tabular}{|c|c|c|c|c|c|c|}
\hline \multirow[b]{2}{*}{ Character } & \multicolumn{3}{|c|}{ Soil depth (Cm) } & \multicolumn{3}{|c|}{ Mechanical analysis } \\
\hline & 0-30 & $30-60$ & $60-90$ & Sand $(\%)$ & $\begin{array}{l}\text { Silt } \\
(\%)\end{array}$ & $\begin{array}{l}\text { Clay } \\
(\%)\end{array}$ \\
\hline PH (1: 2.5) & 7.96 & 8.14 & 8.27 & 52.9 & 30.6 & 16.5 \\
\hline EC (ds/m) & 1.14 & 1.73 & 1.89 & 51.8 & 30.9 & 17.3 \\
\hline $\mathrm{CaCO}_{3}(\%)$ & 34.82 & 36.17 & 36.59 & 50.7 & 31.5 & 17.8 \\
\hline O. M. (\%) & 0.36 & 0.24 & 0.15 & Texture class :- & & \\
\hline Total N (\%) & 0.05 & 0.03 & 0.02 & Sandy silt & & \\
\hline \multicolumn{7}{|c|}{ Soluble cations (meq/L) } \\
\hline $\mathrm{Ca}^{2+}$ & 4.10 & 4.23 & 4.51 & & & \\
\hline $\mathrm{Mg}^{2+}$ & 1.08 & 1.12 & 1.25 & & & \\
\hline $\mathbf{N a}^{+}$ & 8.11 & 8.31 & 8.56 & & & \\
\hline $\mathbf{K}^{+}$ & 1.83 & 2.03 & 2.19 & & & \\
\hline \multicolumn{7}{|c|}{ Soluble anions (meq/L) } \\
\hline $\mathrm{HCO}_{3}^{-}$ & 2.11 & 2.22 & 2.39 & & & \\
\hline $\mathrm{Cl}^{-}$ & 8.53 & 8.75 & 9.13 & & & \\
\hline $\mathrm{SO}_{4}^{2-}$ & 4.48 & 4.72 & 4.99 & & & \\
\hline
\end{tabular}


Table2. Chemical analysis of organic manure (Farm yard)

\begin{tabular}{lccc}
\hline \multicolumn{1}{c}{ Characters } & $\mathbf{2 0 0 8}$ & $\mathbf{2 0 0 9}$ & $\mathbf{2 0 1 0}$ \\
\hline - Moisture content (\%) & 18.60 & 19.20 & 16.24 \\
- Organic matter (\%) & 22.15 & 20.35 & 19.56 \\
- Organic carbon (\%) & 13.56 & 16.11 & 14.78 \\
- Total nitrogen (\%) & 1.04 & 1.07 & 1.11 \\
- C/N ratio & $13: 1$ & $15: 1$ & $13: 1$ \\
- P (\%) & 0.43 & 0.36 & 0.47 \\
- K (\%) & 0.98 & 1.12 & 1.26 \\
- Fe (ppm) & 3190 & 3250 & 4103 \\
- Zn (ppm) & 715 & 549 & 592 \\
- Mn (ppm) & 2616 & 3011 & 2815 \\
\hline
\end{tabular}

Mineral nitrogen was applied as ammonium sulphate $20.6 \% \mathrm{~N}$ at 3 equal batches in February, April and June every season.

Organic manure was broadcasting as farmyard rate at $20 \mathrm{~m}^{3} / \mathrm{fed}$. in January every year. Biofertilizer "nitrobin" produced by General Organization of Agricultural Equilibrium Fund (GOAER), Ministry of Agriculture, Egypt. Nitrobin was added once at the first weak of March every season in crescentic tranches arround each experimental palm in depth of 1 meter neer root area at 1.5 meter far from palm trunk, where each palm received 4 liters of nitrobin solution according to the recommended usage method i.e. 1 packet weights 500 gms per 2 liters water. In addition, all selected palms received $1.5 \mathrm{~kg} / \mathrm{palm}$ and $1 \mathrm{~kg} / \mathrm{palm}$ of calcium superphosphate $\left(15.5 \% \mathrm{P}_{2} \mathrm{O}_{5}\right)$ and potassium sulphate $(50 \%)$ in February and July, respectively. After all treatments, palms were directly irrigated.

The treatments were arranged in randomized complete block design with four replications, each replicate was represented by one palm i.e., 11 treatments $\times 4$ replicates $=44$ experimental palms.

The number of setted fruits per strand was counted using sixteen tagged attached strands/spathe on four random bunches of each palm after one month from the artificial hand pollination, and then at the commerical harvest date (mid of September), number of retained fruits/selected strand were recorded and fruit retention percentage was calculated. In addition, number and weight of bunches/palm were recorded to estimate the total yield/palm.

For determination of physical and chemical properties, two hundred fruits were collected randomly from every experimental palm, then, weight, length, width, pulp weight and flesh thickness of the fruit were recorded.

Total soluble solids (TSS), total acidity, total and reducing sugars of fruit pulp were determined according to the standard methods which are outlined in

A.O.A.C.(1995). Total soluble tannins in fruit pulp were determined according to Swain and Hillis (1959).

For mineral content determination, pinnae samples were collected in the first of November from the middle pinnae of the full developed leaves located just over the fruiting zone (less than one year old) around the axis as recommended by Embleton and Cook (1947). Twenty pinnae per sample for each replicate were taken, washed several times with tap water and rinsed three times with distilled water then dried at $70^{\circ} \mathrm{C}$ to a constant weight. Nitrogen and phosphorus were determined colorimetrically according to Evenhuis (1976) and Murphy and Riely (1962), respectively. Potassium was determined by flame photometer. Iron, manganese and zinc were determined by Perkin Elmer Atomic Absorption Spectrophotometer.

The obtained data were statistically analyzed according to Mead et al. (1993) using L.S.D. test to recognize the significantly between the various treatments.

\section{RESULTS AND DISCUSSION}

I- Effect of mineral, organic and bio nitrogen fertilizers on yield components of Zaghloul date palms:

Data in Table (3) indicated that yield components (fruit retention $\%$, number of bunches/palm, bunch weight and yield/palm) were significantly affected by different levels and combinations of mineral, organic and bio nitrogen fertilizers as compared with that of the control. The results showed that treatment no.10 (25\% Min.N $+50 \%$ Org. $\mathrm{N}+$ Bio-N) produced the highest yield components in the three seasons among all treatments. In the meantime, treatment no.6 (50\% Min. $\mathrm{N}+50 \%$ Org. $\mathrm{N})$ came in the second rank in regard to improvement of tested yield components. However, treatment no.11 (control) gave the lowest yield components values, followed by treatment no.3 (Bio$\mathrm{N})$.

The beneficial effect of organic manure (FYM) to increase both bunch weight and yield per palm may be 
attributed to the role of organic manure in increasing nutrient uptake, which plays an important role in producing favorable balance between growth and fruit production. Also the nutritional status of treated palms could be responsible for the increament of yield due to of its important role in photosynthesis process. In addition, the pronounced effect of organic and biofertilizers on yield and its components may be due to increasing cell division and enlargement, and consequently increasing vegetative growth which reflected on increasing the yield and its components as final result from the physiological processes (Abd ElNaby \& Gomaa, 2000; Geetha \& Nair, 2000 and Shaheen et al., 2009).

These results agreed with those reported by Bhangoo et al. (1988); Ishac (1989); Hussein et al. (1992); Shaheen et al. (2003); Al-Wasfy \& El-Khawaga (2008) and Abd El-Salam et al. (2009).

\section{2- Effect of mineral, organic and bio nitrogen on physical properties of Zaghloul dates:}

Data represented in Table (4) showed that fruit physical properties of Zaghloul date palms i.e. fruit weight, length and width, pulp weight and flesh thickness were significantly improved by different levels and combinations of mineral, organic and bio nitrogen treatments, in comparison with control, in the three experimental seasons. Treatment no.10 (25\% Min.N+50\% Org.N+Bio.N) gave the highest values of fruit weight, pulp weight and flesh thickness, followed by treatment no.6 (50\% Min.N+50\% Org.N) in such parameters. At the sametime, treatment no.5 (100\% Org.N+Bio.N) produced the highest values of fruit length and width, followed by treatment no.10. However, control treatment produced the lowest values in all fruit physical properties, followed by treatment no. 1 (100\% Min.N).

It appears from these results that biofertilizer $\mathrm{N}$ which combined with the above mentioned treatments had an important role in improvement of fruit physical properties. Gogoi et al. (2004); Mai et al. (2005) and Shaheen et al. (2009) indicated that physical properties of fruits increased with $50 \%$ recommended dose of $\mathrm{N}$ plus Azospirillum on banana plants.

In addition, organic $\mathrm{N}$ alone or combined with mineral source can maintain a good balance between growth and fruit which may result in accumulation more carbohydrates and makes them very available for enhancing ripening of fruits (Al-Wasfy and ElKhawaga, 2008). These results were in agreement with those obtained by Osman (2003); Abd El-Hameed and Ragab (2004); Mohamed and Gobara (2004); El-Assar (2005); Diab (2006) and Rabie \& Saad (2007).

\section{3- Effect of mineral, organic and bio nitrogen fertilizers on chemical constituents of Zaghloul dates:}

Data in Table (5) clearly showed that all tested mineral, organic and bio nitrogen treatments significantly improved chemical consitituents of Zaghloul dates compared with control treatment. Where, treatment no.10 (25\% Min.N+50\% Org. $\mathrm{N}+$ Bio.N) followed by treatment no.6 (50\% Min. $\mathrm{N}+50 \%$ Org. $\mathrm{N}$ ) recorded the highest values with regard to total soluble solids (TSS), TSS/acid ratio, total sugars and reducing sugars. However, both of treatment no.11 (control treatment) followed by treatment no.3 (Bio.N) recorded the lowest values. It is worthy to mention, that both of total acidity and soluble tannins values took the conversal trend. These results were true in the three experimental seasons.

The effect of organic and biofertilizers on increasing the $\mathrm{TSS} \%$, reducing and total sugars and decreasing total acidity in fruits could be due to their beneficial effect on the total leaf area of plant which reflected in more carbohydrates production through photosynthesis process that reflect on improvement of chemical properties of fruits (Tiwary et al., 1988; Mansour, 1998; Tachibana \& Yahata, 1998; Joo et al., 1999; Magda, 2002; Mansour et al., 2004 and Shaheen et al., 2009).

Additionally, Umesh et al. (1988) indicated that Azosprillum inoculated coupled with $50 \% \mathrm{~N}$ resulted in the most pronounced increase in amount of total soluble solids as well as reducing sugars content of banana fruits.

These results were in accordance with those reported by Osman (2003); El-Shenawi \& El-Sayed (2005); Basma \& Telep (2008); Hossam El-Deen \& Boshra (2008).

\section{4- Effect of mineral, organic and bio nitrogen fertilizers on leaf mineral content of Zaghloul date palms:}

Data in Table (6) revealed that all of the studied leaf minerals were significantly increased by the combined treatments of mineral, organic and bio nitrogen fertilizers as compared with control treatment. As regard to macronutrients (nitrogen, phosphorus and potassium contents), treatment no.10 (25\% Min.N+50\% Org.N+Bio.N) gave the highest values, followed by treatment no. $6(50 \%$ Min.N+ 50\% Org.N). In the meantime, concerning the micronutrients (iron, manganese and zinc content), treatment no.5 (100\% Org.N+Bio.N) recorded the highest values followed by treatment no.10. However, treatment no.11 (control) and treatment no. 3 (Bio.N) produced the lowest values of leaf mineral content. The other treatments produced 


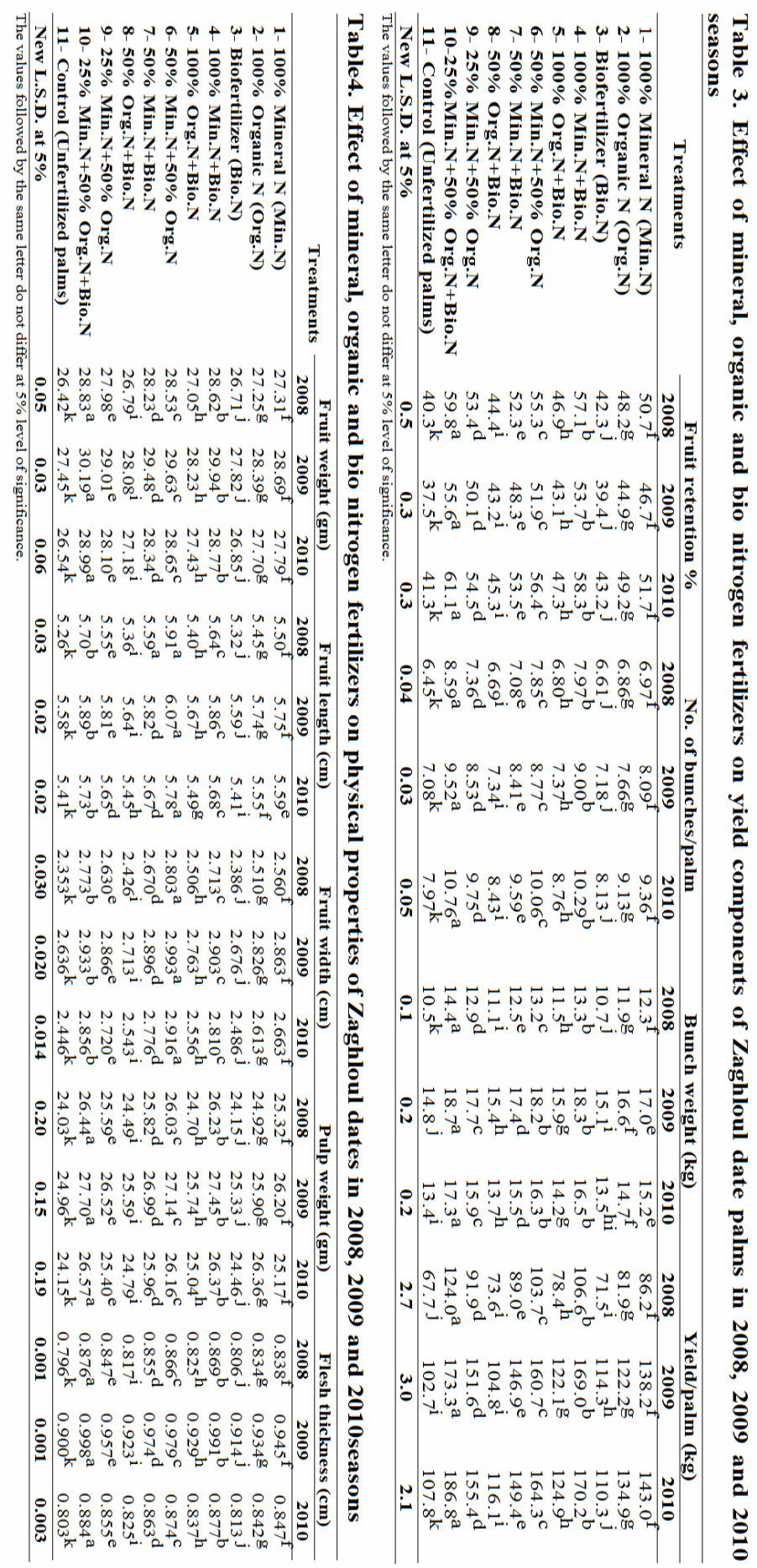




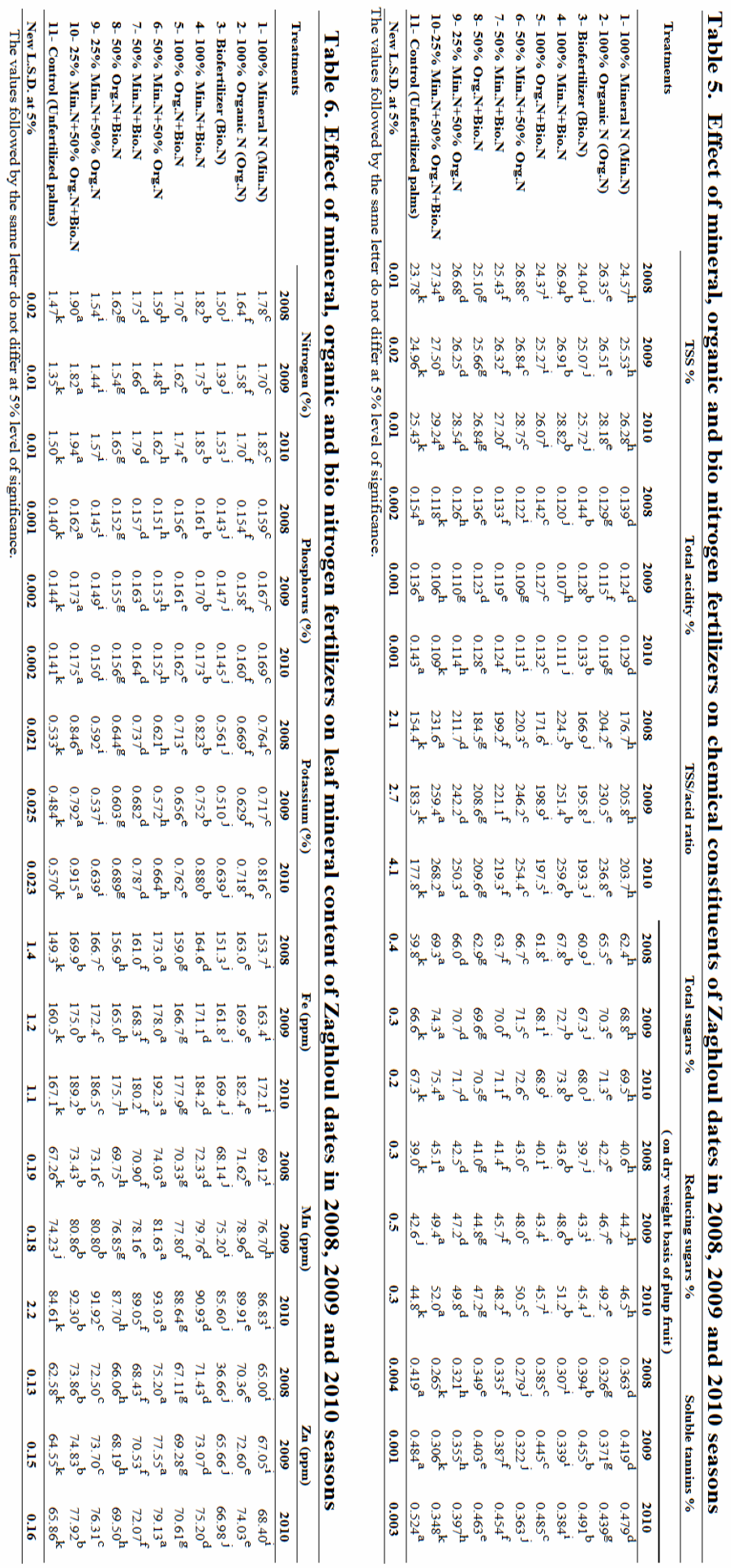


intermediate values of studied leaf mineral content with significant differences between each other in most cases. These results were true for the three experimental seasons.

The positive effect of organic fertilizer on leaf mineral content may be due to its high content of N,P,K beside other nutrients. In addition, the remarkable effect of these organic fertilizers is reducing $\mathrm{pH}$ which may be responsible for increasing avialability of most nutrients (Asker et al., 1994; Smith et al., 1994; Nassar et al., 1998 and Shaheen et al., 2009).

With respect to biofertilizer (nitrobin), it could be used as source for fixing nitrogen in the soil, beside, its pronounced role in improvement of nutrients uptake and protection from root pathogens (Techan, 1988 and Gogoi et al., 2004).

These results were in line with those found by Umesh et al. (1988); Soliman (2001); Magda (2002); Mansour et al. (2004); El-Shenawi \& El-Sayed (2005); Diab (2006) and Al-Wasfy \& El-Khawaga (2008) who indicated that leaf mineral contents was increased by organic and bio nitrogen fertilizers on different fruit trees.

It could be concluded that, fertilizing Zaghloul date palms grown in new reclaimed lands, with $25 \%$ mineral $\mathrm{N}$ (as ammonium sulphate $20.6 \% \mathrm{~N}$ ) $+50 \%$ organic nitrogen (as farmyard) + biofertilizer $\mathrm{N}$ (nitrobin) gave the best results with regard to yield and fruit quality. In addition, such promising treatment minimizes the application of mineral fertilizers and shares in reducing environmental pollution.

\section{RE FERENCES}

Abd El-Hameed, M.A. and M.A. Ragab (2004). Response of Sewy date palm to application of some organic fertilizers. Abstract of the Second Conf. on Date Palm. Fac. Agric., El-Arish, Suez Canal Univ., Egypt.

Abd El-Naby, S.K.M. and A.M. Gomaa (2000). Growth, nutrition status, yield and fruit quality of Maghrabi banana as affected by some organic manures and biofertilizer. Minufiya J. Agric. Res., 25 (4): 1113-1129.

Abd El-Salam, Yasmin G.; Safaa A. Nomier and R.A. AlAshker (2009). Using of some bio and organic fertilizers to reduce the rate of mineral $\mathrm{N}$ fertilization and improving orange tree production. Zagazig J. Agric. Res., Vol.36 No.(4) 691-719.

Al-Wasfy, M.M. and A.A.S. El-Kahwaga (2008). Effect of organic fertilization on growth, yield and fruit quality of Zaghloul date palm grown in sandy soil. Assiut J. of Agric. Sci., 39 (1): 121-133.

Asker, F.A.; S. Marei and H. El-Zaher (1994). Sewage Sludge as natural conditioner characteristics and pore-size distribution. Egypt J. Soil Sci. 34 (1): 67-77.
A.O.A.C. (1995). Association of Official Agricultural Chemists, Official Methods of Analysis $15^{\text {th }}$ Ed. Published by A.O.A.C. Washington, D.C. (USA).

Basma, M. Seleem and A.M. Telep (2008). Effect of organic and bio- fertilizers as a partial substitute for inorganic nitrogen in Superior grapevines. Minia J. of Agric. Res. \& Develop. Vol. (28) No. (1) pp. 23-35.

Bhangoo, M.S.; K.S. Day; V.R. Sudanagunta and V.E. Petrucci (1988). Application of poultry manure influences Thompson seedless grape production and soil properties. Hort. Science. 23 (6): 1010-1012.

Blake, F. (1990). Organic Fanning and Growing. The Crowood Press. New York.

Bogatyre, A.N. (2000). What are we do to eat or how to live longer? Pishchevaya Promyshlennost. 78: 34-35.

Diab, Y.M. (2006). Effect of some cultural practices on yield and fruit quality of Phoenix dactylifera L. cv. Sewy under New Valley conditions. M.Sc. Thesis. Fac. Agric. Assiut Univ., Egypt.

El-Assar, A.M. (2005). Response of "Zaghloul" date yield and fruit characteristics to various organic and inorganic fertilization types as well as fruit thinning models in a rich carbonate soil. J. Agric. Sci. Mansoura Univ., 30 (5): 2795-2814.

El-Shenawi, M.R. and El-Sayed, S.A.M. (2005). Effect of bio and organic fertilization on growth, productivity, fruit quality and leaf mineral content of Grand Nain banana. J. Adv. Agric. Res. (Fac. Agric. Saba Basha), Vol.10 (3).

Embleton, T.W. and J.A. Cook (1947). The fertilizer value of date leaf and fruit stalk prunings. Date growers' Inst. Rept. 24: 18-19.

Evenhuis, B. (1976). Nitrogen determination. Dept. Agric. Res. Royal Tropical Instit., Amsterdam.

Geetha, K. and Nair, R.R. (2000). Integrated plant nutrition system (IPNS) for banana. Ann. of Agric. Res., (India) 21 (4): 499-503.

Gogoi, D.; U. Kotoky and S. Hazarika (2004). Effect of biofertilizers on productivity and soil characteristcs in banana. Indian J. Hort. 61 (4): 354-356.

Hossam El-Deen A.S. and E.S. Boshra (2008). Effect of different sources of organic fertilizers as a partial substitute for mineral nitrogen fertilizer of Williams banana. J. Agric. Sci. Mansoura Univ., 33 (6): 4369-4381.

Hussein, M.A.; S.Z. El-Agamy; K.A. Amen and S. Galal (1992). Effect of certain fertilization and thinning application on the yield and fruit quality of Zaghloul date palm. Assiut J. Agric. Sci., 23 (2): 349-360.

Ishac, Y.Z. (1989). Inoculation with associative $\mathrm{N}_{2}$-fixers, Egypt. nitrogen fixation with non-legumes. Kluwer Academic Publishers. pp. 241-246.

Joo, Y.H. Lee; Y.I.A. Senanayake and I.R. Sangakkara (1999). Effect of EM on the production of crops and waste treatment in Korea. Fifth International Conference on Kyusei Nature Farming, Bongkok, Thailand, 23-26 October, 19W, 151-156. 
Mai, M.A.B.; Z.H. Shamsuddin; W. Zakaria and M. Mohmoud (2005). High yielding and quality banana production through plant growth promoting rhizobacterial (PGRR) inoculation. Fruits Paris, 60 (3): 179-185.

Magda, H. Mostafa (2002). Studies on fertilization of Washington Navel orange trees. Ph.D. Thesis. Fac. Of Agric., Moshtohor, Zagazig Univ.

Mansour, A.E.M. (1998). Response of Anna apples to some biofertilizers. Egypt J. Hort., 25 (2): 241-251.

Mansour, A.E.M.; F.F. Ahmed and Y.M. Ahmed (2004). Effect of bio and organic sources of $\mathrm{N}$ as a partial substitute for mineral fertilizer on fruiting of Sewy date palms. The Second International Conference on Date Palm, Fac. Agric. El-Arish, Suez Canal Univ.

Mead, R.; Currow, R.N. and Harted A.M. (1993). Statistical Methods in Agriculture and Experimental Biology $2^{\text {nd }}$ ed. Chapman \& Hall, London.

Mohamed, G.A. and A.A. Gobara (2004). Response of Sewy date palms grown under New Valley conditions to organic, bio and mineral fertilization. Minia J. of Agric. Res. \& Develop., 24 (3): 397-414.

Murphy, J. and J.P. Riley (1962). A modified single solution method for the determination of phosphorus in natural waters. Anal. Chem. Acta. 27: 31-36.

Nassar, I.N. (1998). Utilization of the municipal garbage (MG), as a soil amendment. Alex. J. Agric. Res., 43 (3): 317-332.

Osman, S.M. (2003). Effect of biofertilization on fruit physical and chemical properties of Zaghloul date palm. Annals Agric. Sci. Ain Shams Univ., Cairo. 48 (1): 297305.

Rabie, I. Saad and M.M. Saad (2007). Effect of different organic nitrogen sources on growth, yield and fruit quality of Williams banana. J. Adv. Agric. Res., Vol.12 (1): 149164.

Shaheen, A.H.; A.M. Attalla; H.A. Kassem and H.S.H. Aly (2003). Effect of applying different organic and inorganic nitrogen sources to Zaghloul and Samany date palm cultivars on: II- Yield, fruit quality and fruit content of some pollutants. Proceedings of the International Conference on Date Palm. King Saud University. Kingdom of Saudi Arabia. P.195-205.
Shaheen, M.A. Eissa; M.M. Saad and S.M. Mahmoud (2009). Influnce of organic and biofertilization on growth, yield and fruit quality of Williams Banana. J. Agric. Sci. Mansoura Univ., 34(7):8013-8025.

Smith, W.H.; K.L. Campbell; W.D. Graham and A.B. Bottcher (1994). Beneficial uses of composts in Florida. Proc. of the second conference, April, 247-253 USA.

Soliman, M.G.A. (2001). Response of banana and guava plants to some biological and mineral fertilizers. M.Sc. Thesis, Fac. Agric., Alex. Univ., Egypt.

Swain, T. and W.E. Hillis (1959). The phenolic constituents of Prunus domestica L. 1- The quantitative analysis of phenolic constituents. J. Sci. Food Agric., 10: 63-68.

Tachibana, S. and S. Yahata (1998). Effects of organic matter and nitrogen fertilizer application on fruit quality of Satsuma mandrin in a high density planting. J. of the Japanese Society of Horticultural Science, 67 (5): 671676.

Techan, Y.T. (1988). Some aspects of non-rhizobial diazotrophs: Their past and their future. In Microbiology in Action, Eds. W.G. Murrcll and I.R. Kennedy. pp.193207. Research Studied Press/Wilcy Chichester, U.K.

Tiwary, D.K.; M.A. Hassan and P.K. Chattopadhyay (1988). Studies on the effect of inoculation with Azotobacter and Azospirillum on growth, yield and quality of banana. Indian Agriculturist, 42 (4): 235-240.

Umesh, K.C.; Krishnappa and D.J. Bagyaraj (1988). Interaction of burrowing nematode Radopholus similis (Cobb, 1893) Thorne 1949 and VA micorrhiza Ghmus Pasciculatum (Thaxl) Gerd and Trappe in banana (Musa acuminta colla). Indian Journal of Nematology, 18 (1): 611.

Wilde, S.A.; R.B. Corey; J.G. Lyer and G.K. Voigt (1985). Soils and plant analysis for tree cultivars. Oxfort, IBH, New Delhi, India pp.94-105. 


\title{
प]
}

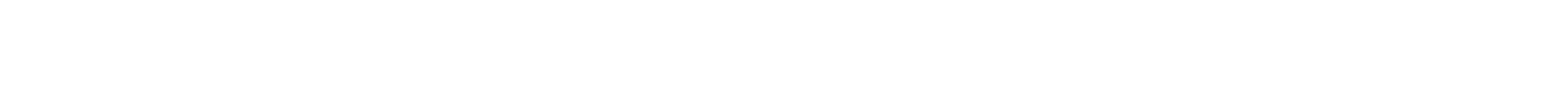

\author{
ربيع إيراهيمسعد، خالد ألّد رشد، [ـوى أبو الدعبد اليد
}

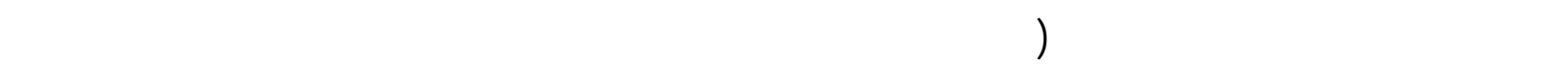

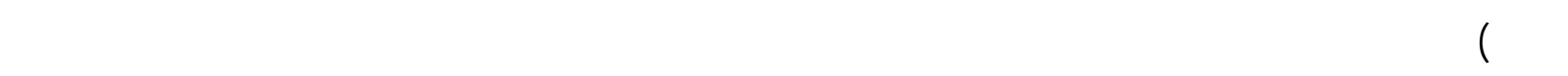

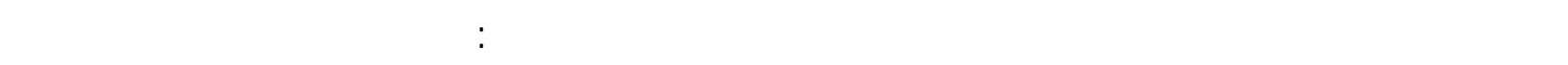

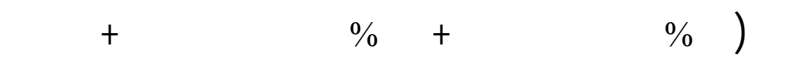
اللمسضلة الديدة - بقاع مريوط.

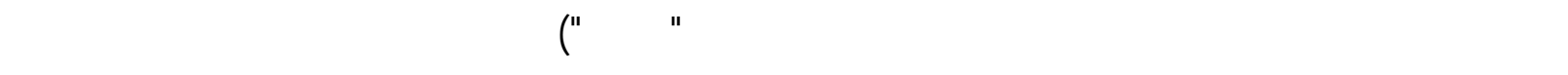

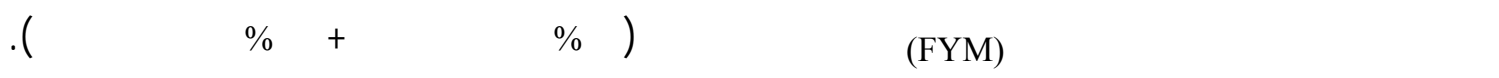

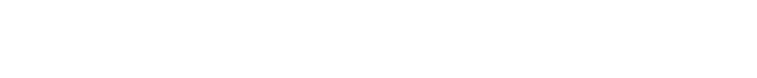

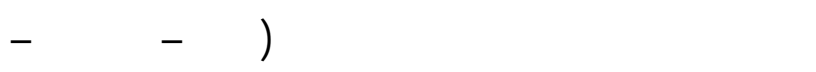

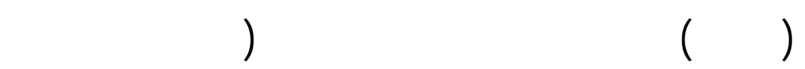

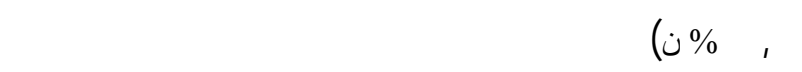

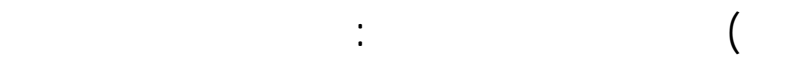

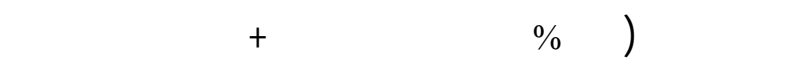

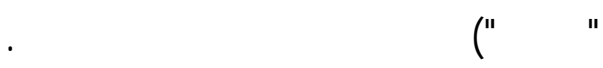

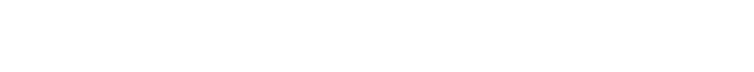

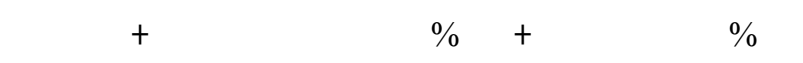

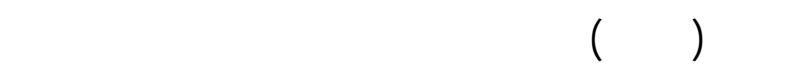

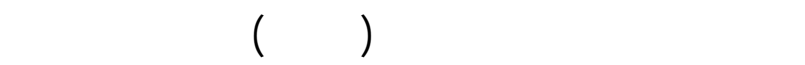

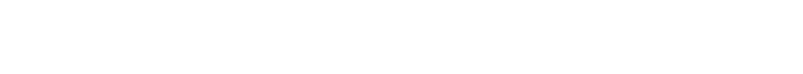

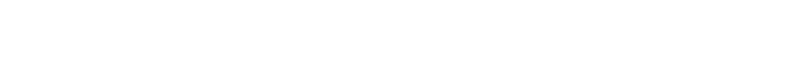

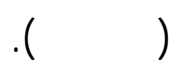

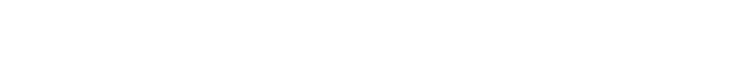

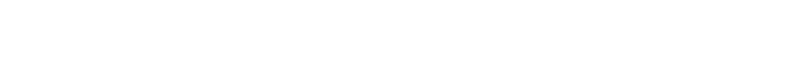

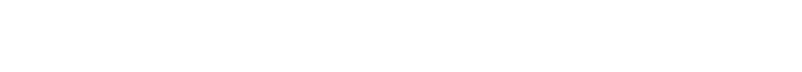

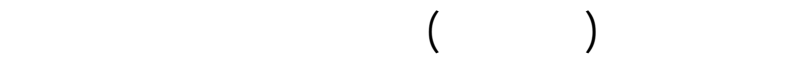

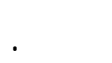

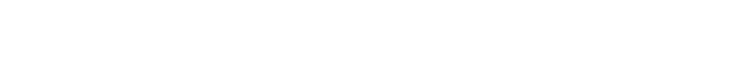

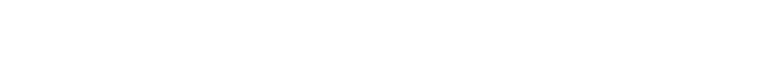
بالأرلف المدية. 